\title{
Efek Mediasi Self Efficacy Terhadap Penerapan Etika Dalam Pendidikan Akuntansi
}

\author{
Vadelin \\ Universitas Katolik Soegijapranata \\ Alin.vadelin@gmail.com \\ Clara Susilawati \\ clara@unika.ac.id
}

\begin{abstract}
Abstrak
Penelitian ini membahas kesenjangan literatur dengan menyelidiki peran self-efficacy dosen menerapkan etika dalam kurikulum akuntansi. Konsep tentang self-efficacy, dalam penelitian ini mendefinisikan self-efficacy dosen akuntansi menerapkan etika dalam perkuliahan sebagai kemampuan seseorang untuk mengatur dan mengintegrasikan pendidikan etika dalam kurikulum akuntansi. Ini termasuk kemampuan dosen akuntansi dalam mendesain konsep etika, penggunaan sumber daya pengajaran etika yang sesuai, dan mengembangkan strategi keterlibatan mahasiswa untuk menerapkan etika pada pendidikan akuntansi. Tujuan keseluruhan dari penelitian ini adalah untuk menguji faktor-faktor yang membentuk selfefficacy dosen akuntansi menerapkan etika dalam perkuliahan. Dalam melakukannya, penelitian ini menilai tiga faktor berikut sebagai predictor self-efficacy dosen akuntansi, yaitu sikap terhadap pendidikan etika, dukungan ketua program studi, dan dukungan rekan kerja. Penelitian ini menggunakan data dari kuesioner yang disebar kepada seluruh dosen akuntansi yang masih aktif pada Universitas berakreditasi A di Semarang sebanyak 106 dosen. Hasil penelitian menunjukkan dukungan ketua program studi dan dukungan rekan kerja berpengaruh signifikan terhadap penerapan etika melalui self-efficacy.
\end{abstract}

Kata Kunci : Self-Efficacy, etika, kurikulum akuntansi,.

\begin{abstract}
This study discusses the literature gap by investigating the role of self-efficacy of lecturers in applying ethics in the accounting curriculum. The concept of self-efficacy, in this study defines the self-efficacy of accounting lecturers to apply ethics in lectures as "one's ability to regulate and integrate ethics education in the accounting curriculum". This includes the ability of accounting lecturers to design ethical concepts, use appropriate ethical teaching resources, and develop student engagement strategies to apply ethics to accounting education. The overall objective of this study is to examine the factors that make the SE (self-efficacy) accounting lecturers applying ethics in lectures. In doing so, this study assessed the following three factors as predictors of accounting lecturers' self-efficacy, is attitudes toward ethics education, study program chair support, and support from colleagues. Data are collected from questionnaires distributed to 106 lecturer of University in Semarang. Result show that support from chair and coworker significantly influence the application of ethics through self-efficacy.
\end{abstract}

Keywords : Self-Efficacy, ethics, accounting curriculum. 


\section{PENDAHULUAN}

Pendidikan etika telah menarik minat besar mengingat kegagalan tenar perusahaan terdepan di masa lalu dan skandal hubungannya dengan kurangnya akuntabilitas dan pengawasan oleh akuntan profesional. Penelitian sebelumnya menunjukkan bahwa integrasi pendidikan etika dalam program akuntansi terus berkembang melintasi berbagai mata pelajaran, dan dalam jenis metode pengajaran dan materi pendukung, misalnya kuliah dan tutorial yang menggabungkan contoh dari buku teks, perdebatan dikelas, analisis kasus nyata dan ulasan artikel/berita.

Namun ada juga persepsi yang dipegang luas diantara dosen akuntansi, yaitu untuk pendidik sendiri masih banyak yang perlu dilakukan untuk memperbaiki kualitas pendidikan etika dibidang akuntansi. Sebagai contoh, analisis konten etika dalam 26 buku teks akuntansi terlaris di Australia oleh Tweedie et al. (2013) mengungkapkan bahwa konten dan sumber daya etis kurang mendalam dan beragam. Penelitian sebelumnya juga menunjukkan kendala waktu, sumber daya yang tidak memadai, kurangnya pengetahuan atau staf yang berkualitas mengenai masalah subjek dan peluang penelitian etika sebagai hambatan yang mungkin terjadi pada integrasi pendidikan etika dalam kurikulum akuntansi.

Beberapa pendapat mengatakan peran yang dimainkan oleh setiap dosen sangat penting, di mana persepsi dan sikapnya cenderung menentukan motivasi seseorang untuk mengintegrasikan pendidikan etika dalam kurikulum akuntansi (Ghaffari et al. 2008; Cavico dan Mujtaba, 2009). Seperti yang dicatat oleh Ghaffari et al. (2008), perkembangan kurikulum itu kompleks, memakan waktu dan proses istimewa yang membutuhkan pemahaman yang lebih mendalam tentang faktor-faktor yang berbeda yang saling mempengaruhi sejauh mana mahasiswa mungkin (atau tidak) tertarik pada pelajaran etika. Namun ada sedikit bukti empiris pada tingkat pendidikan akuntansi mengenai faktor-faktor yang mendorong pengambilan pelajaran etika akuntansi.

Penelitian ini membahas kesenjangan literature dengan menyelidiki peran self-efficacy dosen ketika menerapkan etika dalam kurikulum akuntansi. Konsep dari self-efficacy, awalnya dikembangkan Bandura (1986), yaitu penilaian orang atas kemampuan mereka untuk mengatur dan melaksanakan tindakan yang diperlukan untuk mencapai jenis kinerja yang ditunjukan. Dalam penelitian ini, jenis kinerja dan hasil yang di fokuskan adalah integrasi etika dalam pendidikan akuntansi oleh mahasiswa akuntansi.

Dalam penelitian ini self-efficacy dosen akuntansi dalam menerapkan etika dalam perkuliahan merupakan kemampuan seorang dosen untuk mengatur dan mengintegrasikan pendidikan etika dalam kurikulum akuntansi. Ini termasuk kemampuan dosen akuntansi dalam mendesain konsep etika, penggunaan sumber daya pengajaran etika yang sesuai, dan mengembangkan strategi keterlibatan mahasiswa untuk menerapkan etika pada pendidikan akuntansi. Tujuan keseluruhan dari penelitian ini adalah untuk menguji faktor-faktor yang membentuk self-efficacy dosen akuntansi menerapkan etika dalam perkuliahan. Dalam melakukannya, penelitian ini menilai tiga faktor berikut sebagai predictor self-efficacy dosen akuntansi: 1. Sikap terhadap pendidikan etika (STPE). 2. Dukungan ketua program studi (DKPS). 3. Dukungan rekan kerja (DRK).

\section{TINJAUAN LITERATUR DAN PERUMUSAN HIPOTESIS}

\section{Penerapan Etika}

Dorongan pertama yang terorganisir untuk memasukkan etika ke dalam kurikulum bisnis terjadi pada tahun 1979, ketika asosiasi untuk meningkatkan sekolah bisnis Collagiate membuat pendidikan etika menjadi persyaratan bagi siswa dalam program 
pendidikan bisnis. Baru-baru ini, Federasi Akuntansi Internasional meminta standar kurikulum yang lebih tinggi diseluruh wilayah melalui pengumuman Standar Pendidikan Internasional. Nilai untuk profesi professional awal, etika dan sikap (IFAC, 2016) dalam Dellaportas (2017). Kejadian seperti itu didasarkan pada gagasan bahwa tidak adanya pendidikan etika sama sekali.

Penelitian mendalam tentang pendidikan etika akuntansi telah meneliti rancangan kurikulum, keefektifan kursus dan tingkat pendidikan etika, yang semuanya merupakan elemen penting. Rancangan kurikulum berpusat pada isu apakah etika harus diajarkan sebagai materi yang terintegrasi dalam semua pelajaran (Blanthorne dkk, 2007; Dellaportas, 2014; Ghaffari dkk, 2008) dalam Dellaportas (2017); efektivitas meneliti pengaruh intervensi etika terhadap kepekaan etis mahasiswa atau pengembangan penalaran moral (Dellaportas dkk, 2006) dalam Dellaportas (2017); dan tingkat pemeriksaan jumlah dan/atau perubahan pokok bahasan etika dalam kurikulum akuntansi (Dellaportas, 2014; Bampton dan Cowton, 2002) dalam Dellaportas (2017).

Penelitian saat ini ditempatkan dibagian terakhir dimana "tingkat penerapan" diukur dan dipengaruhi oleh self-efficacy. Sementara bukti menunjukkan bahwa dosen akuntansi percaya bahwa pendidikan etika didorong dan dihargai, cakupan etika tetap tidak memadai dan diperlukan lebih banyak pendidikan etika. Pendidikan etika bukanlah bagian yang konsisten dan terpadu dari pendidikan bagi banyak siswa akuntansi (Blanthorne dkk, 2007; Bampton dan Cowton, 2002; Dellaportas, 2014) dalam Dellaportas (2017). Tinjauan literature yang relevan oleh Dellaportas dkk (2014) dalam Dellaportas (2017) menyoroti beberapa faktor yang berpotensi menghambat integrasi dan perluasan pendidikan etika kedalam kurikulum akuntansi, termasuk pelatihan, sumber daya, ruang kurikulum terbatas dan perjuangan untuk legitimasi akademis.

\section{Kerangka Konseptual}

Kerangka konseptual untuk penelitian ini berdasarkan teori self-efficacy Bandura (1977) dalam Dellaportas (2017) dan teori kongnitif sosial yang lebih luas (Bandura, 1986;2006) dalam Dellaportas (2017). Menurut teori kognitif sosial, orang memperoleh dan memelihara pola perilaku tertentu dengan mengamati orang lain dalam lingkungan sosial, dan seringkali dengan cara yang berkaitan dengan kemampuannya untuk membentuk interaksi (Bandura 2006) dalam Dellaportas (2017). Selanjutnya, hal ini dicontohkan oleh Bandura (2012) dalam Dellaportas (2017) melalui model penentuan timbal balik triadiknya dimana fungsi manusia dilihat sebagai hasil interaksi antara faktor pribadi individu, perilaku mereka, dan pengaruh lingkungan (Wood \& Bandura, 1989) dalam Dellaportas (2017). Beberapa asosiasi kritis diusulkan, yaitu :

1. Faktor lingkungan yang berpotensi mempengaruhi kognisi pribadi,

2. Kognisi pribadi akan membentuk perilaku seseorang,

3. Tindakan perilaku pada gilirannya akan mempengaruhi lingkungan.

Dalam kerangka ini, self-efficacy dipandang sebagai sifat kritis individu yang dapat memiliki pengaruh penting pada pola pikir, pembelajaran dan emosi mereka yang memungkinkan dan membentuk perilaku dan tindakan selanjutnya.

Menurut Bandura (1997) dalam Dellaportas (2017), self-efficacy individu dibangun dari empat sumber yang berasal dari refleksi, pengamatan, persuasi, dan stimulasi. Sumber pertama self-efficacy adalah pencapaian kinerja atau penguasaan, yang berakitan dengan penilaian seseorang atas hasil tindakannya, dalam hal keberhasilan masa lalu atau kegagalan mereka dalam tugas serupa. Sumber kedua pembentukkan self-efficacy berhubungan dengan pengalaman atau permodelan yang berhubungan dengan pembelajaran mengamati orang lain yang menurut pengamatannya memiliki kemampuan yang serupa dengan dirinya. Negara fisiologis dan efektif adalah sumber ketiga yang dapat 
membentuk self-efficacy, dimana persepsi individu dan kecenderungan emosional terhadap konteks atau isu tertentu ikut bermain. Sumber informasi keempat dan yang terakhir yang mempengaruhi keefektifan diri adalah persuasi sosial (terkadang disebut sebagai persuasi lisan).

Konsep self-efficacy telah diadopsi dibanyak disiplin ilmu termasuk manajemen, psikologi, dan pendidikan (pendidikan yang sebagian besar adalah pendidikan menengah). Dalam konteks pendidikan, self-efficacy didefinisikan sebagai "Kepercayaan seorang guru terhadap kemampuannya untuk mengatur dan melaksanakan tindakan yang dibutuhkan untuk berhasil menyelesaikan tugas pengajaran tertentu dalam konteks tertentu".(Tschannen-Moran dkk, 1998) dalam Dellaportas (2017). Bukti empiris mendukung keefektifan diri guru sebagai predictor signifikan untuk pembelajaran dan kinerja siswa (Moore dan Esselman, 1992; Ross, 1992; Tschannen-Moran dan Hoy, 2001) dalam Dellaportas (2017) termasuk perilaku guru yang positif, seperti pengembangan praktik instruksional dan antusiasme guru dan komitmen (Skaalvik dan Skaalvik, 2007; Wolters dan Daugherty, 2007) dalam Dellaportas (2017). Guskey (1988) dalam Dellaportas (2017) menemukan bahwa guru dengan tingkat self-efficacy lebih kuat lebih terbuka terhadap gagasan baru dan lebih bersedia untuk bereksperimen dengan metode baru untuk meningkatkan dampaknya terhadap siswa.self-effiicacy guru juga dikaitkan dengan membantu siswa belajar dan mempromosikan hubungan positif (Narvaez dkk, 2008) dalam Dellaportas (2017). Namun, salah satu kritiknya adalah "masih belum jelas bagaimana keegoisan guru untuk pendidikan moral terkait dengan perilaku guru yang spesifik" (Narvaez dkk, 2008) dalam Dellaportas (2017).

Self-efficacy disebut sebagai keyakinan individu bahwa ia mampu mengerjakan suatu tugas (Robbins dan Timothy, 2008). Maka dari itu semakin tinggi self-efficacy yang dimiliki seseorang maka semakin besar pula kepercayaan diri yang di miliki oleh orang tersebut. Menurut Robbins dan Timothy (2008), peneliti yang mengembangkan teori selfefficacy, Albert Bandura, menyabutkan ada 4 cara untuk meningkatkan self-efficacy, yaitu

a. Penguasaan yang tetap

b. Contoh yang dilakukan oleh individu lain

c. Bujukan verbal

d. Kemunculan

Dalam studi ini, kami berpendapat bahwa dosen akuntansi dengan self-efficacy yang lebih besar dalam mengajarkan etika yaitu penerapan etika lebih cenderung mengintegrasikan konten etika kedalam mata kuliah dan subjek mereka, dan faktor individu dan lingkungan yang membentuk PE. Perkembangan hipotesis untuk penelitian ini sebagian besar berasal dari sumber self-efficacy seperti yang diusulkan oleh Bandura (1997;2006) dalam Dellaportas (2017) dan temuan empiris terkait dari penelitian sebelumnya (misalnya Blanthorne dkk, 2007; Cohen dan Pant, 1989; Evans dan Marcal, 2005; dan Tschannen-Moran dan Hoy, 2001) dalam Dellaportas (2017).

\section{Sikap Terhadap Pendidikan Etika}

Sikap adalah kecenderungan psikologis yang diungkapkan dengan mengevaluasi entitas tertentu dengan tingkat yang baik atau tidak (Eagly dan Chaiken, 1993) dalam Dellaportas (2017). Pada studi ini, titik fokus dalam dimensi ini adalah pendapat dosen akuntansi terhadap pentingnya dan dampak pendidikan etika akuntansi untuk profesi dan masyarakat secara keseluruhan.

Secara khusus konseptualisasi kami terhadap STPE sangat menarik dari daftar keyakinan obyektif Blanthorne dkk (2007) dalam Dellaportas (2017) tentang mengapa etika harus (atau tidak harus) diterapkan, yang berasal dari tinjauan ekstensif terhadap 
survey masa lalu dan literature opini mengenai etika, diskusi peraturan baru-baru ini, dan pers popular. Sebagai contoh, sikap kepercayaan bahwa "kepercayaan publik perlu dibentuk kembali karena skandal akuntansi baru-baru ini" atau bahwa "pengembangan etis sangat penting bagi profesi akuntansi" boleh dibilang memiliki potensi untuk menginspirasi dan mempromosikan pendidikan etika (Blanthorne dkk, 2007) dalam Dellaportas (2017).

\section{Dukungan Pemimpin (Ketua Program Studi)}

Menurut teori sosial kognitif (Bandura, 1997) dalam Dellaportas (2017), lingkungan termasuk faktor kontekstual ditempat kerja yang memiliki potensi untuk mempengaruhi konsepsi individu tentang dirinya dan juga perilaku mereka.

Kepemimpinan adalah faktor kontekstual kritis yang memiliki implikasi untuk penetapan tujuan karyawan, kepuasan kerja dan identitas sosial (Leithwood dan Jantzi, 1999; Reicher dkk, 2005) dalam Dellaportas (2017). Pemimpin dapat menunjukkan dukungan melalui berbagai jalan, misalnya alokasi sumber daya, struktur penghargaan, dan sanksi dari apa yang dapat dan tidak dapat diterima.

Dalam bidang pendidikan, dukungan interpersonal kepala administrasi, perguruan tinggi, orang tua, dan anggota masyarakat telah terbukti mempengaruhi keefektifan diri guru (Tschannen-Moran dan Hoy, 2001; Woolfolk dkk, 1990) dalam Dellaportas (2017) melalui Negara-negara fisiologis / afektif serta persuasi sosial / verbal.

Sebagai contoh, kepala sekolah telah menemukan sesuatu hal untuk mengubah penilaian guru tentang kinerjanya, meningkatkan pertukaran pengalaman perwakilan dan terlibat dalam persuasi sosial (Ross, 1994) dalam Dellaportas (2017). Literatur self-efficacy guru berpendapat bahwa hubungan antara kepemimpinan kepala sekolah dan self-efficacy guru dapat dipengaruhi oleh tiga faktor umum (Hipp dan Bredeson, 1995; Supovits dkk, 2010) dalam Dellaportas (2017).

Pertama, kepala sekolah yang mampu mengilhami tujuan bersama di antara para guru dapat menciptakan lingkungan dimana para guru merasakan keberhasilan yang lebih besar. Kedua, kepala sekolah yang menyediakan sumber daya untuk guru dan melindunginya dari faktor yang mengganggu, tetapi membiarkan fleksibilitas dalam urusan kelas, menciptakan konteks yang memungkinkan pengembangan diri yang kuat. Ketiga, prinsipal yang memodelkan perilaku yang tepat dan memberi penghargaan bagi kinerja, kemungkinan besar akan meningkatkan kepercayaan dan self-efficacy guru.

\section{Dukungan Rekan}

Dukungan rekan disebut sebagai sistem pemberian dan penerimaan bantuan, didasarkan pada prinsip-prinsip utama, yaitu rasa hormat, tanggung jawab bersama dan kesepakatan budaya yang sangat membantu (Mead, Hilton, dan Curtis, 2001) dalam Dellaportas (2017). Dalam penelitian ini, dukungan rekan mengacu pada sejauh mana dosen akuntansi mulai membentuk hubungan sosial dan pemahaman diantara rekan kerja yang mencakup berbagai sumber daya dan tanggung jawab terkait etika akuntansi. Menurut Bandura (1997) dalam Dellaportas (2017), pembentukan self-efficacy muncul dari pengalaman luar biasa, yaitu belajar dengan mengamati orang lain dan juga dari persuasi sosial, yaitu dorongan lisan dari orang lain.

\section{Sikap Terhadap Pendidikan Etika, Self-Efficacy, dan penerapan etika}

Menurut Bandura (2006) dalam Dellaportas (2017), keadaan fisiologis atau emosional individu mempengaruhi penilaian self-efficacy sehubungan dengan tugas tertentu. Pandangan yang lebih optimis atau positif adalah semakin besar rasa self-efficacy seseorang yang kemudian mempengaruhi tujuan dan aspirasi pribadi, motivasi dan ketekunan dalam mengahadapi masalah dan kesulitan. 
Mengikuti pendapat Bandura (2006) dalam Dellaportas (2017), kami berpendapat bahwa dosen akuntansi yang lebih baik dan positif, semakin besar kecenderungan mereka untuk percaya pada kemampuan dan komitmen mereka terhadap penerapan etika. Contohnya, karena para dosen lebih memahami pendidikan etika sebagai hal yang kritis terhadap profesi dan kepentingan publik, semakin besar keyakinan bahwa seseorang dapat secara pribadi menyampaikan pentingnya nilai etika di kelas mereka maka semakin besar tingkat penerapan etika dalam mata kuliah yang di ampuh. Sebaliknya, mereka yang memiliki sikap negative terhadap pendidikan akuntansi cenderung tidak percaya diri dalam kemampuan mereka untuk menyampaikan pentingnya etika maka semakin kecil juga tingkat penerapan etika dalam mata kuliah yang di ampuh. Dengan demikian, STPE dosen akuntansi diharapkan dapat memiliki efek yang signifikan dan positif terhadap PE mereka melalui self-efficacy.

Menurut teori sosial kognitif Bandura (2012) dalam Dellaportas (2017), tindakan manusia pada umumnya merupakan fungsi dari persepsi dan sikap mereka. Penelitian sebelumnya (Gunz dan McCutcheon, 1998; Madison dan Schmidt, 2006; Adkins dan Radtke, 2004; Williams dan Elson, 2010) dalam Dellaportas (2017) juga telah mengamati bahwa lebih banyak sikap positif terhadap pentingnya etika dalam perkuliahan akuntansi, ada kesediaan yang lebih kuat diantara dosen akuntansi yang ingin belajar dan memimpin inovasi pendidikan etika dan perubahan kurikulum.

Berdasarkan pembahasan diatas, kami berpendapat bahwa sikap positif terhadap kebutuhan dan dampak pendidikan etika akuntansi akan menghasilkan cakupan etika yang lebih besar oleh dosen akuntansi. Oleh karena itu, himpunan pertama hipotesis dalam penelitian ini adalah sebagai berikut :

\section{H1: sikap dosen akuntansi terhadap pendidikan etika berpengaruh terhadap tingkat penerapan etika dalam mata kuliah melalui self-efficacy dosen akuntansi}

\section{Dukungan Ketua Program Studi, Self-Efficacy dan Penerapan Etika}

Ketua program studi akuntansi berpotensi mendukung dosen akuntansi dalam menciptakan lingkungan yang memungkinkan mereka bebas dan percaya diri dalam mecoba dan menerapkan etika pada pendidikan akuntansi. Beberapa fungsi utama ketua program studi mencakup keterlibatan aktif dengan promosi mengenai misi dan tujuan organisasi, dorongan kolaborasi lingkungan dan kepercayaan di fakultas, dan memiliki kemampuan untuk mendukung peningkatan instruksional melalui alokasi sumber daya (Supovitz dkk, 2010) dalam Dellaportas (2017). Kami mengusulkan bahwa persuasi sosial pemimpin administratif, seperti DKPS akuntansi, merupakan pengaruh utama pada peningkatan SE dosen akuntansi (Bandura 2006) dalam Dellaportas (2017).

DKPS dapat mempengaruhi staf mereka melalui tujuan komunikasi, pengawasan, dan evaluasi organisasi, dan dorongan langsung dan tidak langsung dari perilaku spesifik untuk mencapai tujuan fakultas yang diinginkan. DKPS berada dalam posisi penting untuk membangun struktur dan insentif untuk memotivasi dan mengkoordinasikan integrasi pendidikan etika. Jadi hipotesis kedua penelitian ini adalah sebagai berikut :

\section{H2: dukungan ketua program studi berpengaruh terhadap tingkat penerapan etika dalam mata kuliah melalui self-efficacy dosen akuntansi.}

\section{Dukungan Rekan Kerja, Self-Efficacy, dan Penerapan Etika}

Dukungan rekan mengacu pada bantuan dan dorongan yang diberikan oleh individu yang dianggap setara (Dennis, 2003) dalam Dellaportas (2017). Studi sebelumnya dalam konteks pendidikan disekolah telah menemukan pengaruh positif antara dukungan rekan dan self-efficacy. Misalnya, self-efficacy ditemukan meningkat saat guru bekerja sama 
untuk menemukan cara mengatasi masalah belajar, motivasi dan perilaku siswa mereka (Tschannen-Moran dkk, 1998) dalam Dellaportas (2017) dan bantuan yang diberikan oleh rekan-rekan untuk mengembangkan materi kelas (Mulholland dan Wallace, 2001) dalam Dellaportas (2017). Penelitian oleh Milner dan Hoy (2003), Rosenholtz (1989), dan smylie (1988) (dalam Dellaportas, 2017) juga menekankan proses persuasi sosial seperti umpan balik verbal, interaksi, dorongan dan pujian sebagai faktor vital dalam menciptakan lingkungan kerja yang mendukung.

Demikian juga, dalam penelitian ini, kami mengusulkan dukungan rekan yang lebih tinggi, seperti menerima umpan balik dan panduan positif dalam kaitannya dengan pengajaran etika akuntansi, akan mengarahkan pada SE akademis yang lebih tinggi sehingga akan memiliki efek berupa tingkat penerapan etika dalam mata kuliah yang di ampuh lebih tinggi pula. Akibatnya, meningkatkan dukungan rekan cenderung meningkatkan keyakinan dan kepercayaan diri terhadap kemampuan mereka dalam mengajarkan etika.

Penelitian sebelumnya menemukan bahwa dukungan rekan memiliki dampak langsung terhadap tindakan dan perilaku guru. Supovitz dkk (2010) dalam Dellaportas (2017) menemukan bahwa ada pengaruh kuat dan signifikan antara rekan guru dan praktik mengajar guru. Secara khusus, penelitian ini menemukan bahwa tingkat percakapan instruksional yang lebih tinggi, interaksi disekitar jaringan pengajaran dan pembelajaran dan nasehat diantara guru sebaya, dikaitkan dengan peningkatan jumlah perubahan dalam instruksi yang dilaporkan guru. Berdasarkan pembahasan sebelumnya, himpunan hipotesis ketiga dari penelitian ini adalah sebagai berikut :

\section{H3: dukungan rekan kerja berpengaruh terhadap tingkat penerapan etika dalam mata kuliah melalui self-efficacy dosen akuntansi.}

\section{METODE PENELITIAN}

\section{Populasi dan Sampel}

Sampel penelitian adalah dosen tetap akuntansi yang mengajar di Universitas yang memiliki akreditasi A, yang berlokasi di Universitas Diponegoro Semarang, Universitas Katolik Soegijapranata Semarang, Universitas Dian Nuswantoro Semarang, Universitas Stikubank, Universitas Negeri Semarang (forlap, 2018). Sampel penelitian ini mencakup dosen tetap akuntansi di Universitas yang memiliki akreditasi A yang masih aktif pertahun ajaran 2017/2018 berjumlah 106 orang. Data yang digunakan dalam penelitian ini adalah data primer. Data primer adalah data yang dikumpulkan dan diolah sendiri oleh suatu organisasi atau perorangan langsung dari obyeknya.

\section{Pengukuran Variabel Penerapan Etika}

Penerapan etika adalah persepsi dosen akuntansi mengenai keterlibatan kasus etika yang diterapkan dalam perkuliahan. Tingkat penerapan etika oleh dosen akuntansi, yaitu PE diukur menggunakan skala 8 item yang dikembangkan oleh Blanthorne dkk (2007). Dan responden perlu menunjukkan sejauh mana mereka setuju atau tidak setuju dengan masingmasing item pada skala likert lima poin ( $1=$ 'sangat tidak setuju', $3=$ 'netral', $5=$ 'sangat setuju').

Semakin tinggi skor yang diperoleh, berarti dosen akuntansi semakin sering melibatkan kasus etika yang diterapkan dalam perkuliahan. Sebaliknya, semakin rendah skor yang diperoleh, maka dosen akuntansi semakin sedikit melibatkan kasus etika yang diterapkan dalam perkuliahan. 


\section{Sikap Terhadap Pendidikan Etika}

Sikap dosen akuntansi terhadap pendidikan etika (STPE) adalah persepsi dosen akuntansi terhadap sikap yang dihasilkan dari proses pendidikan etika saat ini. Instrument yang digunakan untuk mengukur sikap terhadap pendidikan etika terdiri dari 7 pertanyaan yang dikembangkan oleh Blanthorne dkk (2007). Dan responden perlu menunjukkan sejauh mana mereka setuju atau tidak setuju dengan masing-masing item pada skala likert lima poin ( $1=$ 'sangat tidak setuju', $3=$ 'netral', $5=$ 'sangat setuju').

Semakin tinggi skor yang diperoleh berarti semakin baik persepsi dosen akuntansi terhadapsikap yang dihasilkan dari proses pendidikan etika saat ini. Sebaliknya, semakin rendah skor yang diperoleh, maka semakin buruk pula persepsi dosen akuntansi terhadap sikap yang dihasilkan dari proses pendidikan etika saat ini.

\section{Dukungan Ketua Program Studi}

Dukungan yang diberikan ketua program studi adalah persepsi dosen mengenai dukungan finansial dan non finansial oleh ketua program studi dalam membina pendidikan etika. Untuk penelitian ini, kami menggunakan enam item dimana item tersebut berkaitan dengan persepsi DKPS mengenai dukungan moral dan alokasi waktu untuk pengembangan kurikulum etika. Instrument yang digunakan untuk mengukur persepsi dukungan ketua program studi ini dikembangkan oleh Blanthorne dkk (2007). Kuesioner terdiri dari enam item, dimana responden setuju atau tidak setuju dengan masing-masing item pada skala likert lima poin ( $1=$ 'sangat tidak setuju', $3=$ 'netral', $5=$ 'sangat setuju').

Semakin tinggi skor yang diperoleh berarti responden berpersepsi bahwa semakin disediakan dukungan finansial dan non finansial oleh ketua program studi dalam membina pendidikan etika. Sebaliknya, semakin rendah pula skor yang diperoleh, maka responden berpersepsi bahwa semakintidak disediakannya dukungan finansial dan non finansial ketua program studi dalam membina pendidikan etika.

\section{Dukungan Rekan}

Dukungan rekan (DR) adalah persepsi dosen akuntansi mengenai rekan kerja dilingkungan pengajaran dapat berbagi pengetahuan dan sumber daya yang terkait dengan pengembangan etika pada pendidikan akuntansi. Dalam penelitian ini, kami menilai DR berdasarkan kuesioner yang terdiri dari lima item yang dikembangkan oleh McCormick dkk (2006) dimana dimensi fokusnya adalah "silabus yang berkaitan dengan etika" dan "berbagai sumber daya dan pengetahuan terkait etika" dari konteks pendidikan tinggi. Responden menanggapi setiap item menggunakan skala likert lima poin $(1=$ 'sangat tidak setuju', 3 = 'netral', 5 = 'sangat setuju').

Semakin tinggi skor yang diperoleh responden mempunyai persepsi bahwa rekan kerjanya semakin sering berbagi pengetahuan terkait dengan penerapan etika pendidikan akuntansi. Sebaliknya, semakin rendah skor yang diperoleh, maka responden mempunyai persepsi bahwa rekan kerjanya semakin sering tidak berbagi pengetahuan terkait dengan penerapan etika pendidikan akuntansi.

\section{Self-Efficacy}

Self-efficacy adalah persepsi dosen akuntansi mengenai frekuensi keterlibatan dosen dalam memotivasi mahasiswa untuk berpikir etis dalam perkuliahan. Dalam penelitian ini, kami menggunakan 15 item pertanyaan. Instrument yang digunakan untuk mengukur selfefficacy akademisi akuntansi diperoleh dari Teacher Sense of Efficacy Scale (TSES) Semua lima belas item pertanyaan yang menggunakan skala likert lima poin $(1=$ 'sangat tidak setuju', 3 = 'netral', 5 = 'sangat setuju'). 
Semakin tinggi skor yang diperoleh berarti dosen akuntansi memiliki frekuensi keterlibatan lebih besar dengan mahasiswa dalam memotivasi mahasiswa untuk berpikir etis dalam perkuliahan. Sebaliknya, semakin rendah skor yang diperoleh, maka dosen akuntansi memiliki frekuensi keterlibatan sangat sedikit dengan mahasiswa dalam memotivasi mahasiswa untuk berpikir etis dalam perkuliahan.

\section{Pengujian Hipotesis}

Uji hipotesis dalam penelitian ini menggunakan uji variabel mediasi (intervening). Variabel mediasi adalah variabel yang dapat memediasi atau menjembatani hubungan antar variabel lain (Muniarti, 2013). Mediasi menyiratkan hipotesis kausal dimana sebuah variabel independen mempengaruhi variabel mediator, dan variabel mediator mempengaruhi variabel dependen (Holland, 1988; Sobel, 1990) dalam Murniati (2013).

Pengujian dengan variabel mediasi merupakan pengujian model yang dimana variabel independen berpengaruh terhadap variabel dependen yang merupakan pengaruh dari perubahan variabel mediasi, lalu perubahan variabel mediasi tersebut yang mempengaruhi perubahan variabel dependen (Murniati, 2013). berikut :

Langkah-langkah dalam melakukan uji hipotesis variabel mediasi ini adalah sebagai

\section{Sikap terhadap pendidikan etika:}

Langkah 1 : menguji pengaruh sikap terhadap pendidikan etika terhadap penerapan etika, dengan model empiris sebagai berikut :

\section{$\mathrm{PE}=\beta_{0.1}+\beta_{1.1} \mathrm{STPE}$}

Langkah 2 :.menguji pengaruh langsung sikap terhadap pendidikan etika terhadap selfefficacy, dengan model empiris sebagai berikut :

$\mathrm{SE}=\beta_{0.2}+\beta_{1.2} \mathrm{STPE}$

Langkah 3 : menguji pengaruh langsung sikap terhadap pendidikan etika dan selfefficacy terhadap penerapan etika, dengan model empiris sebagai berikut :

$\mathrm{PE}=\beta_{0.3}+\beta_{1.3} \mathrm{STPE}+\beta_{2.3} \mathrm{SE}$

Langkah 4 : membandingkan c dan c'

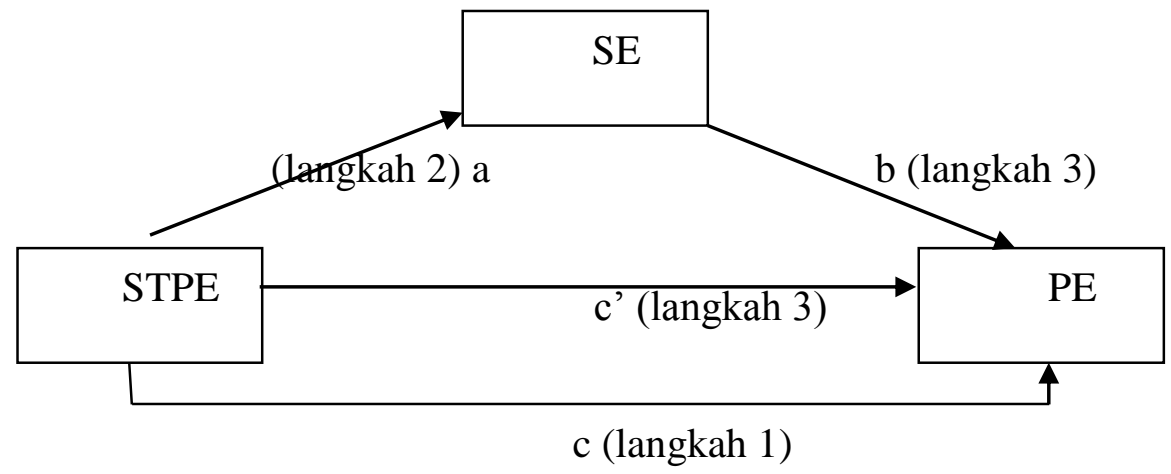

Dukungan ketua program studi :

Langkah 1 : menguji pengaruh dukungan ketua program studi terhadap penerapan etika, dengan model empiris sebagai berikut :

$\mathrm{PE}=\beta_{0.1}+\beta_{1.1}$ DKPS

Langkah 2 :.menguji pengaruh langsung dukungan ketua program studi terhadap selfefficacy, dengan model empiris sebagai berikut :

$\mathrm{SE}=\beta_{0.2}+\beta_{1.2}$ DKPS 
Langkah 3 : menguji pengaruh langsung dukungan ketua program studi dan selfefficacy terhadap penerapan etika, dengan model empiris sebagai berikut :

$\mathrm{PE}=\beta_{0.3}+\beta_{1.3}$ DKPS $+\beta_{2.3} \mathrm{SE}$

Langkah 4 : membandingkan c dan c'

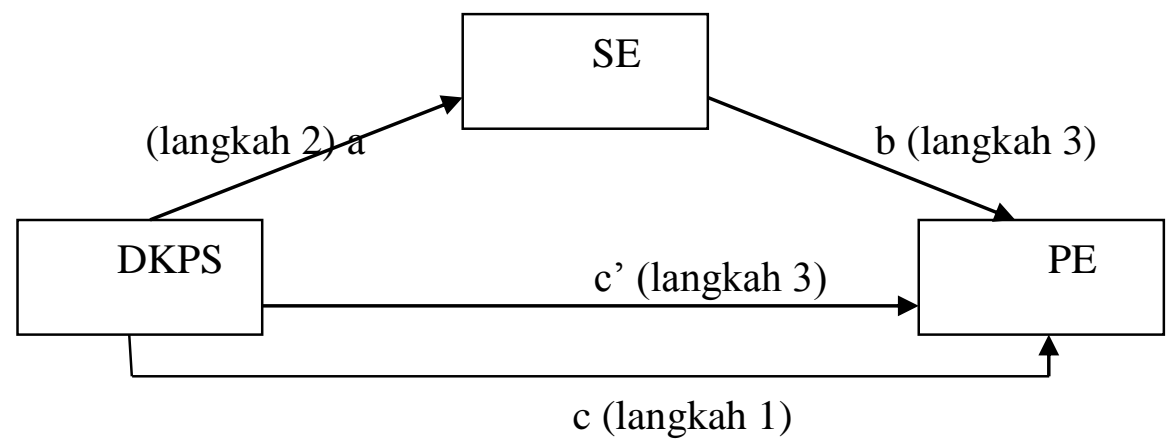

\section{Dukungan rekan kerja:}

Langkah 1 = menguji pengaruh dukungan rekan kerja terhadap penerapan etika, dengan model empiris sebagai berikut :

$\mathrm{PE}=\beta_{0.1}+\beta_{1.1}$ DRK

Langkah 2 :.menguji pengaruh langsung dukungan rekan kerja terhadap self-efficacy, dengan model empiris sebagai berikut :

$\mathrm{SE}=\beta_{0.2}+\beta_{1.2}$ DRK

Langkah 3 : menguji pengaruh langsung dukungan rekan kerja dan self-efficacy terhadap penerapan etika, dengan model empiris sebagai berikut :

$\mathrm{PE}=\beta_{0.3}+\beta_{1.3} \mathrm{DRK}+\beta_{2.3} \mathrm{SE}$

Langkah 4 : membandingkan $\mathrm{c}$ dan c'

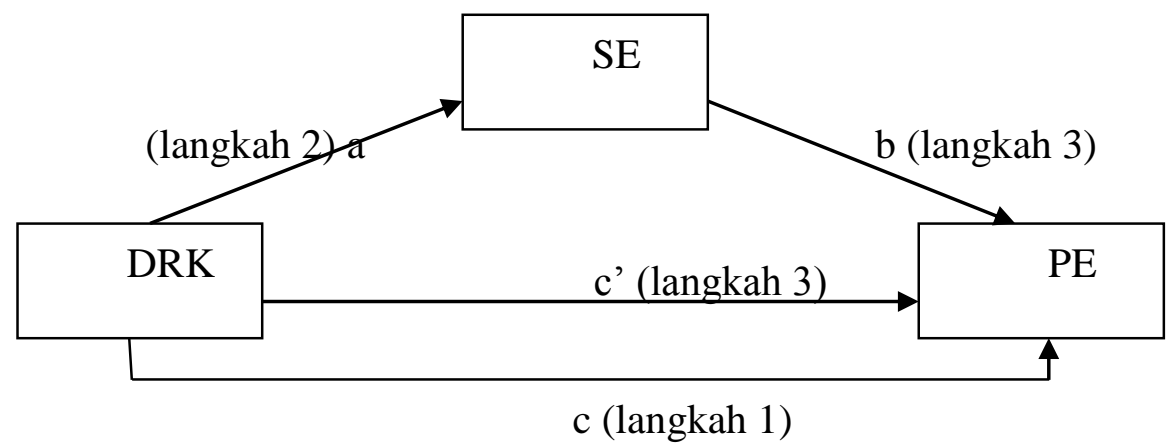

Kriteria penerimaan variabel mediasi ada dua jenis, yaitu :

a. Complete mediation, yaitu ketika variabel $\mathrm{X}$ tidak lagi mempengeruhi $\mathrm{Y}$ setelah hubungan keduanya dikontrol oleh variabel mediasi dan path c' $=0$ (nol) tidak signifikan.

b. Partial mediation, yaitu ketika variabel $\mathrm{X}$ ke $\mathrm{Y}$ menurun $\left(\mathrm{c}^{\prime}<\mathrm{c}\right)$, namun tetap signifikan ketika variabel mediasi mengontrol hubungan keduanya.

\section{HASIL DAN PEMBAHASAN}

Dari tabel 1 dapat dilihat dari nilai rata-rata nya, bahwa sikap terhadap pendidikan etika tergolong dalam kategori sedang yang berarti persepsi dosen akuntansi terhadap pendidikan etika tergolong cukup baik. Untuk dukungan ketua program studi, masuk kategori tinggi yang berarti responden berpersepsi bahwa ketua program studi sangat menyediakan dukungan finansial dan non finansial dalam membina pendidikan etika. 
Untuk dukungan rekan kerja termasuk dalam kategori tinggi, yang berarti responden berpersepsi bahwa rekan kerjanya sangat sering berbagi pengetahuan terakait dengan penerapan etika pendidikan akuntansi. Untuk self-efficacy tergolong kategori tinggi, yang berarti responden berpersepsi bahwa dosen akuntansi memiliki frekuensi keterlibatan yang besar dengan mahasiswa dalam memotivasi mahasiswa untuk berpikir etis dalam perkuliahan. Untuk penerapan etika tergolong kategori tinggi, yang berarti responden berpersepsi bahwa dosen akuntansi sangat sering melibatkan kasus etika yang diterapkan dalam perkuliahan pada Universitasnya.

Tabel 1.

Statistik Deskriptif

\begin{tabular}{|c|c|c|c|c|c|c|c|}
\hline \multirow{2}{*}{ Variabel } & \multirow{2}{*}{$\begin{array}{c}\text { Kisaran } \\
\text { Teoritis }\end{array}$} & \multirow{2}{*}{$\begin{array}{c}\text { Kisaran } \\
\text { Aktual }\end{array}$} & \multirow{2}{*}{ Mean } & \multicolumn{3}{|c|}{ Rentang Skala } & \multirow{2}{*}{$\begin{array}{c}\text { Keteran } \\
\text { gan }\end{array}$} \\
\cline { 5 - 7 } STPE & $1-5$ & $2,29-4,71$ & 3,6304 & $1-2,33$ & $2,34-3,67$ & $3,68-5$ & Sedang \\
\hline DKPS & $1-5$ & $3,00-5,00$ & 3,8862 & $1-2,33$ & $2,34-3,67$ & $3,68-5$ & Tinggi \\
\hline DRK & $1-5$ & $2,60-5,00$ & 3,7492 & $1-2,33$ & $2,34-3,67$ & $3,68-5$ & Tinggi \\
\hline SE & $1-5$ & $3,07-5,00$ & 3,9598 & $1-2,33$ & $2,34-3,67$ & $3,68-5$ & Tinggi \\
\hline PE & $1-5$ & $2,75-5,00$ & 3,7560 & $1-2,33$ & $2,34-3,67$ & $3,68-5$ & Tinggi \\
\hline
\end{tabular}

\section{Uji Hipotesis Satu}

Hipotesis pertama dalam penelitian ini memiliki tiga persamaan, sebagai berikut:

1. PE $=\beta_{0.1}+\beta_{1.1}$ STPE

2. $\mathrm{SE}=\beta_{0.2}+\beta_{1.2} \mathrm{STPE}$

3. $\mathrm{PE}=\beta_{0.3}+\beta_{1.3} \mathrm{STPE}+\beta_{2.3} \mathrm{SE}$

Langkah 1 : sikap terhadap pendidikan etika terhadap penerapan etika.Pengaruh DTPE terhadap PE ditampilkan dalam tabel 2.

Tabel 2. Pengaruh STPE Terhadap PE

Coefficients

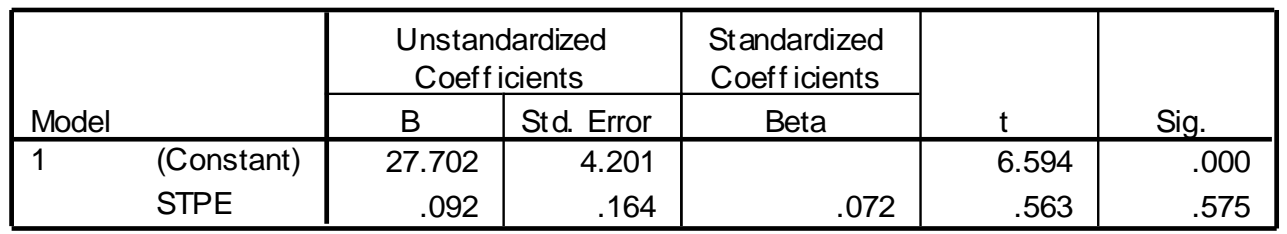

a. Dependent Variable: PE

Sehingga tampak hasil pengujian sebagai berikut : PE $=27,702+0,092$ STPE dan dapat dilihat signifikansi pada persamaan pertama dalam hipotesis ini adalah 0,575 > 0,05, sehingga dinyatakan tidak signifikan.

Langkah 2 : sikap terhadap pendidikan etika terhadap self-efficacy. 
Tabel 3.

Uji Hipotesis STPE Terhadap SE

Coefficients

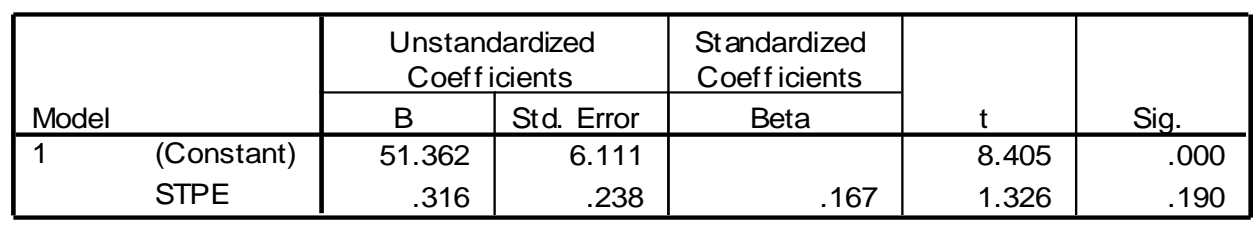

a. Dependent Variable: SE

Sehingga tampak hasil pengujian sebagai berikut :

$\mathrm{SE}=51,362+0,316 \mathrm{STPE}$

Signifikansi pada persamaan kedua dalam hipotesis ini adalah 0,190>0,05, sehingga dapat dinyatakan tidak signifikan etika.

.Langkah 3 : sikap terhadap pendidikan etika dan self-efficacy terhadap penerapan

Tabel 4.

Pengaruh STPE Dan SE Terhadap PE

Coefficients ${ }^{\mathrm{a}}$

\begin{tabular}{|c|c|c|c|c|c|c|}
\hline \multirow{2}{*}{\multicolumn{2}{|c|}{ Model }} & \multicolumn{2}{|c|}{$\begin{array}{l}\text { Unstandardized } \\
\text { Coeff icients }\end{array}$} & \multirow{2}{*}{$\begin{array}{c}\text { Standardized } \\
\text { Coeff icients } \\
\text { Beta } \\
\end{array}$} & \multirow[b]{2}{*}{$t$} & \multirow[b]{2}{*}{ Sig. } \\
\hline & & $\mathrm{B}$ & Std. Error & & & \\
\hline \multirow[t]{3}{*}{1} & (Constant) & -1.284 & 3.553 & & -.361 & .719 \\
\hline & STPE & -.086 & .096 & -.067 & -.900 & .372 \\
\hline & SE & .564 & .051 & .831 & 11.136 & .000 \\
\hline
\end{tabular}

a. Dependent Variable: PE

Dari tabel 4 diketahu nilai Sig. variabel mediasi STPE 0,372 >0,05, sehingga dapat dinyatakan tidak signifikan, dan SE $0,000<0,05$ sehingga dinyatakan signifikan.

Langkah 4 : membandingkan c dan c'

$\mathrm{c}=0,092$ dan $p$-value $=0,575$

$c^{\prime}=-0,086$ dan $p$-value $=0,372$

Berdasarkan hasil tersebut, pengaruh STPE terhadap PE menurun $(0,092$ menjadi $0,086)$ setelah dimasukkan variabel self-efficacy ( -value $\mathrm{c}=0,575$ menjadi $p$-value $\mathrm{c}^{\prime}=$ 0,372) namun tidak signifikan. Berarti persepsi dosen akuntansi terhadap sikap yang dihasilkan dari proses pendidikan etika saat ini tidak mempengaruhi persepsi dosen akuntansi mengenai keterlibatan kasus etika yang diterapkan dalam perkuliahan melalui persepsi dosen akuntansi mengenai frekuensi keterlibatan mahasiswa dalam memotivasi mahasiswa untuk berpikir etis dalam perkuliahan. Dengan demikian H1 ditolak.

\section{Uji Hipotesis Dua}

Hipotesis kedua dalam penelitian ini memiliki tiga persamaan, sebagai berikut :

1. $\mathrm{PE}=\beta_{0.1}+\beta_{1.1}$ DKPS

2. $\mathrm{SE}=\beta_{0.2}+\beta_{1.2} \mathrm{DKPS}$

3. $\mathrm{PE}=\beta_{0.3}+\beta_{1.3}$ DKPS $+\beta_{2.3} \mathrm{SE}$

Langkah 1 : dukungan ketua program studi terhadap penerapan etika. 
Tabel 5.

Pengaruh DKPS Terhadap PE

Coefficients

\begin{tabular}{|c|c|c|c|c|c|c|}
\hline \multirow{2}{*}{\multicolumn{2}{|c|}{ Model }} & \multicolumn{2}{|c|}{$\begin{array}{c}\text { Unstandardized } \\
\text { Coefficients }\end{array}$} & \multirow{2}{*}{$\begin{array}{l}\text { Standardized } \\
\text { Coeff icients } \\
\text { Beta }\end{array}$} & \multirow[b]{2}{*}{$t$} & \multirow[b]{2}{*}{ Sig. } \\
\hline & & $B$ & Std. Error & & & \\
\hline \multirow[t]{2}{*}{1} & (Constant) & 15.913 & 4.002 & & 3.976 & .000 \\
\hline & DKPS & .606 & .170 & .415 & 3.561 & .001 \\
\hline
\end{tabular}

a. Dependent Variable: PE

Dari tabel 5 diketahui nilai Sig. 0,001<0,05 sehingga dapat dinyatakan signifikan.

Langkah 2 : dukungan ketua program studi terhadap self-efficacy.

Tabel 6.

Pengaruh DKPS Terhadap SE

Coefficients

\begin{tabular}{|c|c|c|c|c|c|c|}
\hline \multirow{2}{*}{\multicolumn{2}{|c|}{ Model }} & \multicolumn{2}{|c|}{$\begin{array}{l}\text { Unstandardized } \\
\text { Coeff icients }\end{array}$} & $\begin{array}{l}\text { Standardized } \\
\text { Coeff icients }\end{array}$ & \multirow[b]{2}{*}{$t$} & \multirow[b]{2}{*}{ Sig. } \\
\hline & & $B$ & Std. Error & Beta & & \\
\hline \multirow[t]{2}{*}{1} & (Constant) & 36.313 & 5.746 & & 6.320 & .000 \\
\hline & DKPS & .990 & .244 & .460 & 4.050 & .000 \\
\hline
\end{tabular}

a. Dependent Variable: SE

Dari tabel 6 dapat dilihat Sig. $0,000<0,05$ sehingga dapat dinyatakan signifikan.

Langkah 3 : dukungan ketua program studi dan self-efficacy terhadap penerapan etika.

Tabel 7.

Pengaruh DKPS dan SE Terhadap PE

Coefficients

\begin{tabular}{|rl|r|r|r|r|r|}
\hline \multirow{2}{*}{ Model } & \multicolumn{2}{|c|}{$\begin{array}{c}\text { Unstandardized } \\
\text { Coeff icients }\end{array}$} & \multicolumn{2}{c|}{$\begin{array}{c}\text { Standardized } \\
\text { Coeff icients }\end{array}$} & \\
\cline { 3 - 5 } & B & \multicolumn{1}{|c|}{ Std. Error } & \multicolumn{1}{|c|}{ Beta } & \multicolumn{1}{c|}{ Sig. } \\
\hline 1 & (Constant) & -3.760 & 3.262 & & -1.153 & .254 \\
& DKPS & .070 & .122 & .048 & .575 & .567 \\
& SE & .542 & .057 & .797 & 9.588 & .000 \\
\hline
\end{tabular}

a. Dependent Variable: PE

Dari tabel 7 dapat dilihat DKPS tidak berpengruh signifikan terhadap PE dan SE berpengaruh signifikan terhadap PE.

Langkah 4 : membandingkan c dan c'

$\mathrm{c}=0,606$ dan $p$-value $=0,001$

$c^{\prime}=0,070$ dan $p$-value $=0,567$

Berdasarkan hasil-hasil pengujian hipotesis yang dilakukan dapat diketahui pengaruh DKPS terhadap PE menurun $(0,606$ menjadi $-0,070)$ setelah dimasukkan variabel selfefficacy ( $p$-value $\mathrm{c}=0,001$ menjadi $p$-value $\left.\mathrm{c}^{\prime}=0,567\right)$ menjadi tidak signifikan. Berarti persepsi dosen mengenai dukungan finansial dan non finansial oleh ketua program studi dalam membina pendidikan etika mempengaruhi persepsi dosen akuntansi mengenai keterlibatan kasus etika yang diterapkan dalam perkuliahan melalui persepsi dosen akuntansi mengenai frekuensi keterlibatan mahasiswa dalam memotivasi mahasiswa untuk 
berpikir etis dalam perkuliahan. Dengan demikian H2 diterima dengan model complete mediation.

\section{Uji Hipotesis Tiga}

Hipotesis ketiga dalam penelitian ini memiliki tiga persamaan, sebagai berikut :

1. $\mathrm{PE}=\beta_{0.1}+\beta_{1.1} \mathrm{DRK}$

2. $\mathrm{SE}=\beta_{0.2}+\beta_{1.2} \mathrm{DRK}$

3. $\mathrm{PE}=\beta_{0.3}+\beta_{1.3} \mathrm{DRK}+\beta_{2.3} \mathrm{SE}$

Langkah 1 : dukungan rekan kerja terhadap penerapan etika.

Tabel 8.

\section{Pengaruh DRK Terhadap PE}

Coefficients

\begin{tabular}{|c|c|c|c|c|c|c|}
\hline \multirow{2}{*}{\multicolumn{2}{|c|}{ Model }} & \multicolumn{2}{|c|}{$\begin{array}{l}\text { Unstandardized } \\
\text { Coeff icients }\end{array}$} & \multirow{2}{*}{$\begin{array}{c}\text { Standardized } \\
\text { Coefficients } \\
\text { Beta }\end{array}$} & \multirow[b]{2}{*}{$\mathrm{t}$} & \multirow[b]{2}{*}{ Sig. } \\
\hline & & $B$ & Std. Error & & & \\
\hline \multirow[t]{2}{*}{1} & (Constant) & 18.699 & 2.993 & & 6.247 & .000 \\
\hline & DRK & .605 & .157 & .442 & 3.845 & .000 \\
\hline
\end{tabular}

a. Dependent Variable: PE

Dari tabel 8 dapat dilihat bahwa DRK berpengaruh signifikan terhadap PE. Langkah berikutnya adalah menguji pengaruh DRK terhadap SE.

Langkah 2 : dukungan rekan kerja terhadap self-efficacy.

Tabel 9.

\section{Pengaruh DRK Terhadap SE}

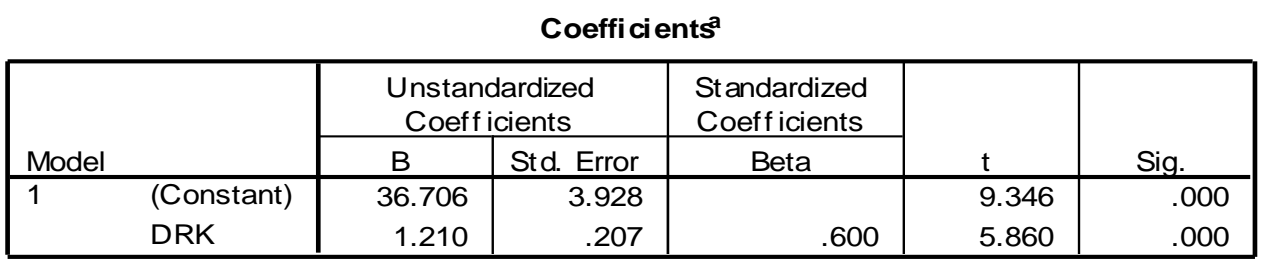

a. Dependent Variable: SE

Dari tabel 9 dapat dilihat bahwa DRK berpengaruh signifikan terhadap SE. Langkah berikutnya menguji pengaruh DRK dan SE terhadap PR

Langkah 3 : dukungan rekan kerja dan self-efficacy terhadap penerapan etika. 
Tabel 10.

Pengaruh DRK Dan SE Terhadap PE

\section{Coefficients ${ }^{\mathrm{a}}$}

\begin{tabular}{|ll|r|r|r|r|r|}
\hline \multirow{2}{*}{ Model } & \multicolumn{2}{|c|}{$\begin{array}{c}\text { Unstandardized } \\
\text { Coeff icients }\end{array}$} & $\begin{array}{c}\text { Standardized } \\
\text { Coefficients }\end{array}$ & & \\
\cline { 3 - 5 } & & \multicolumn{1}{c|}{ B } & Std. Error & Beta & $\mathrm{t}$ & Sig. \\
\hline 1 & (Constant) & -2.904 & 2.990 & & -.971 & .335 \\
& DRK & -.107 & .126 & -.078 & -.849 & .399 \\
& SE & .589 & .063 & .866 & 9.416 & .000 \\
\hline
\end{tabular}

a. Dependent Variable: PE

Dari tabel 10 dapat dilihat bahwa DRK tidak berpengaruh signifikan terhadap PE, sementara SE berpengaruhi signifikan. Langkah berikutnya membandingkkan c dan c'.

Langkah 4 : membandingkan c dan c'.

$\mathrm{c}=0,605$ dan $p$-value $=0,000$

$c^{\prime}=-0,107$ dan $p$-value $=0,399$

Berdasarkan hasil-hasil sebelumnya dapat diketahui bahwa pengaruh DRK terhadap PE menurun $(0,605$ menjadi -0,107) setelah dimasukkan variabel self-efficacy $(p$-value $\mathrm{c}=$ 0,000 menjadi $p$-value $\left.c^{\prime}=0,399\right)$ dan menjadi tidak signifikan. Berarti persepsi dosen akuntansi mengenai rekan kerja dilingkungan pengajaran dapat berbagi pengetahuan dan sumber daya yang terkait dengan pengembangan etika pada pendidikan akuntansi mempengaruhi persepsi dosen akuntansi mengenai keterlibatan kasus etika yang diterapkan dalam perkuliahan melalui persepsi dosen akuntansi mengenai frekuensi keterlibatan mahasiswa dalam memotivasi mahasiswa untuk berpikir etis dalam perkuliahan. Dengan demikian $\mathrm{H} 3$ diterima dengan model complete mediation.

\section{Pembahasan}

Pada hasil pengujian hipotesis yang telah dilakukan menunjukkan bahwa sikap terhadap pendidikan tidak mempengaruhi secara langsung dan tidak langsung penerapan etika melalui self-efficacy. Namun berbeda dengan dukungan ketua program studi dan dukungan rekan kerja yang mempengaruhi penerapan etika melalui self-efficacy.

Hasil penelitian ini mengkonfirmasi penelitian Dellaportas (2017) di Malaysia yang menyatakan hasil bahwa tidak ada pengaruh langsung antara sikap terhadap pendidikan etika dan dukungan ketua program studi terhadap penerapan etika. Dengan demikian selfefficacy memainkan peran mediasi penting untuk menghubungkan sikap terhadap pendidikan etika terhadap penerapan etika, dan dukungan ketua program studi terhadap penerapan etika.

Variabel sikap terhadap pendidikan etika menggunakan teori Bandura (2006) dalam Dellaportas 2017, yakni keadaan fisiologis atau emosional individu mempengaruhi penilaian self-efficacy sehubungan dengan tugas tertentu. Hasil penelitian ini tidak konsisten dengan penelitian Dellaportas (2017) yang menyatakan bahwa sikap terhadap pendidikan etika memiliki pengaruh tidak langsung secara signifikan terhadap penerapan etika melalui self-efficacy, dan dalam penelitian ini sikap terhadap pendidikan etika tidak memiliki pengaruh langsung terhadap penerapan etika dan tidak memiliki pengaruh tidak langsung terhadap penerapan etika melalui self-efficacy.

Dalam penelitian ini, dapat dilihat dari hasil uji hgipotesis menunjukkan uji hipotesis pada persamaan pertama $\mathrm{PE}=27,702+0,092 \mathrm{STPE}$, namun pada persamaan pertama 
memiliki tingkat signifikansi sebesar 0,575 >0,05, sehingga dinyatakan tidak signifikan. Maka dapat disimpulkan persamaan pertama ditolak. Pada persamaan kedua hasil persamaan nya adalah $\mathrm{SE}=51,362+0,316 \mathrm{STPE}$, namun memiliki tingkat signifikansi $0,190>0,05$, sehingga dinyatakan tidak signifikan. Maka dapat disimpulkan bahwa persamaan kedua di tolak. Pada persamaan ketiga terdapat hasil persamaan $\mathrm{PE}=-1,284+$ $(-0,086)$ STPE + 0,564 SE, namun memiliki tingkat signifikansi 0,000 > 0,05, sehingga dinyatakan signifikan. Maka dapat disimpulkan persamaan ke 3 diterima. Dan yang terakhir adalah membandingkan c dan c' $(0,092, p$-value $=0,575$ dan -0,086, $p$-value $=0,372)$. Berdasarkan hasil tersebut, pengaruh STPE terhadap PE menurun ( 0,092 menjadi -0,086) setelah dimasukkan variabel self-efficacy ( $p$-value $\mathrm{c}=0,575$ menjadi $p$-value $\left.\mathrm{c}^{\prime}=0,372\right)$, namun dapat dilihat pada persamaan satu sampai kedua, memiliki signifikansi $>0,05$, sehingga menjadi tidak signifikan, maka dapat disimpulkan bahwa H1 ditolak.

Maka, persepsi dosen akuntansi terhadap sikap yang dihasilkan dari proses pendidikan etika saat ini tidak mempengaruhi persepsi dosen akuntansi mengenai keterlibatan kasus etika yang diterapkan dalam perkuliahan melalui persepsi dosen akuntansimengenai keterlibatan mahasiswa dalam memotivasi mahasiswa untuk berpikir etis dalam perkuliahan. Sehingga hipotesis pertama berbunyi, sikap dosen akuntansi terhadap pendidikan etika etika (STPE) berpengaruh terhadap tingkat penerapan etika (PE) dalam mata kuliah yang di ampu melalui self-efficacy (SE) dosen akuntansi ditolak.

Hipotesis pertama didukung oleh pendapat Bandura dalam Woolfolk (2007: p.128) mengutarakan bahwa karakteristik individu yang memiliki self-efficacy yang tinggi adalah ketika individu tersebut merasa yakin bahwa mereka mampu secara efektif menangani situasi yang mereka hadapi, tekun dalam menyelesaikan tugas-tugas, percaya kepada kemampuan diri yang mereka miliki, memandang kesulitan sebagai tantangan bukan ancaman dan suka mencari situasi baru, menetapkan sendiri tujuan yang menantang dan meningkatkan komitmen yang kuat terhadap dirinya, menanamkan usaha yang kuat dalam apa yang dilakukannya dan meningkatkan usaha saat menghadapi kegagalan, berfokus pada tugas dan memikirkan strategi dalam menghadapi kesulitan, cepat memulihkan rasa mampu setelah mengalami kegagalan dan menghadapi stress dan ancaman dengan keyakinan bahwa mereka mampu mengontrolnya (dalam Hamidah, 2014). Yang penulis berpendapat bahwa seberapa besar persepsi tentang pendidikan etika saat ini, tidak akan mempengaruh self-efficacy dalam melakukan penerapan etika.

Variabel dukungan ketua program studi, menggunakan teori Bandura (2006) dalam Dellaportas (2017), yaitu persuasi sosial pemimpin administratif, seperti ketua program studi akuntansi, memiliki pengaruh utama pada peningkatan self-efficacy dosen akuntansi. Hasil penelitian ini konsisten dengan penelitian Dellaportas (2017), yang menyatakan bahwa dukungan ketua program studi memiliki pengaruh tidak langsung secara signifikan terhadap penerapan etika melalui self-efficacy.

Dalam penelitian ini, dapat dilihat pada uji hipotesis persamaan pertama mendapatkan hasil $\mathrm{PE}=15,913+0,606 \mathrm{DKPS}$, dan memiliki nilai signifikansi $0,001<0,05$, sehingga dapat dinyatakan signifikan, maka persamaan pertama diterima. Pada persamaan kedua mendapatkan hasil $\mathrm{SE}=36,313+0,990$ DKPS, dan memiliki nilai signifikansi $0,000<$ 0,05, sehingga dapat dinyatakan signifikan, maka persamaan kedua diterima. Pada persamaan ketiga mendapatkan hasil $\mathrm{PE}=-3,760+0,070 \mathrm{DKPS}+0,542 \mathrm{SE}$, dan memiliki signifikansi SE $0,000<0,05$, sehingga dapat dinyatakan signifikan, makan persamaan ketiga diterima. Pada bagian akhir dilakukan perbandingan c dan c' $(0,606, p$-value $=0,001$ dan -0,070, $p$-value $=0,567)$. Hasil tersebut menunjukkan pengaruh DKPS terhada PE menurun $(0,606$ menjadi -0,070) setelah dimasukkan variabel self-efficacy ( $p$-value $\mathrm{c}=$ 0,001 menjadi $p$-value $\left.c^{\prime}=0,567\right)$ menjadi tidak signifikan, namun pada persamaan 
pertama sampai ketiga dinyatakan signifikan, maka dapat disimpulkan bahwa hipotesis ke dua di terima dengan model complete mediation.

Maka, persepsi dosen mengenai dukungan finansial dan non finansial oleh ketua program studi dalam membina pendidikan etika mempengaruhi persepsi dosen akuntansi mengenai keterlibatan kasus etika yang diterapkan dalam perkuliahan melalui persepsi dosen akuntansi mengenai frekuensi keterlibatan mahasiswa dalam memotivasi mahasiswa untuk berpikir etis dalam perkuliahan. Sehingga hipotesis kedua berbunyi dukungan ketua program studi (DKPS) berpengaruh terhadap tingkat penerapan etika (PE) dalam mata kuliah yang di ampu melalui self-efficacy (SE) dosen akuntansi diterima dengan model complete mediation.

Variabel dukungan rekan kerja, menggunakan teori Dennis (2013) dalam Dellaportas (2017), yakni dukungan rekan mengacu pada bantuan dan dorongan yang diberikan oleh individu yang dianggap setara. Hasil penelitian ini konsisten dengan penelitian Dellaportas (2017), yang menyatakan bahwa dukungan rekan bepengaruh tidak langsung secara signifikan terhadap penerapan etika melalui self-efficacy.

Dalam penelitian ini, dapat dilihat pada uji hipotesis persamaan pertama mendapatkan hasil $\mathrm{PE}=18,699+0,605 \mathrm{DRK}$, dan memiliki nilai signifikansi $0,000<0,05$, sehingga dapat dinyatakan signifikan, maka persamaan pertama diterima. Pada persamaan kedua mendapatkan hasil $\mathrm{SE}=36,706+1,210 \mathrm{DRK}$, dan memiliki nilai signifikansi $0,000<0,05$, sehingga dapat dinyatakan signifikan, maka persamaan kedua diterima. Pada persamaan ketiga mendapatkan hasil $\mathrm{PE}=-2,904+(-0,107) \mathrm{DRK}+0,589 \mathrm{SE}$, dan memiliki signifikansi SE $0,000<0,05$, sehingga dapat dinyatakan signifikan, makan persamaan ketiga diterima. Pada bagian akhir dilakukan perbandingan c dan c' $(0,605, p$-value $=0,000$ dan $-0,107, p$-value $=0,399)$. Hasil tersebut menunjukkan pengaruh DRK terhada PE menurun $(0,605$ menjadi $-0,107)$ setelah dimasukkan variabel self-efficacy ( $p$-value $\mathrm{c}=$ 0,000 menjadi $p$-value c' $=0,399)$ menjadi tidak signifikan, namun pada persamaan pertama sampai ketiga dinyatakan signifikan, maka dapat disimpulkan bahwa hipotesis ke tiga di terima dengan model complete mediation.

Maka, persepsi dosen akuntansi mengenai rekan kerja dilingkungan pengajaran dapat berbagi pengetahuan dan sumber daya yang terakait dengan pengembangan etika pada pendidikan akuntansi mempengaruhi persepsi dosen akuntansi mengenai keterlibatan kasus etika yang diterapkan dalam perkuliahan melalui persepsi dosen akuntansi mengenai frekuensi keterlibatan mahasiswa dalam memotivasi mahasiswa untuk berpikir etis dalam perkuliahan. Sehingga hipotesis ketiga berbunyi dukungan rekan kerja (DRK)berpengaruh terhadap tingkat penerapan etika (PE) dalam mata kuliah yang di ampu melalui self-efficacy (SE) dosen akuntansi diterima dengan model complete mediation.

\section{KESIMPULAN DAN SARAN}

\section{Kesimpulan}

Dari hasil penelitian yang telah dilakukan, dapat disimpulkan bahwa :

1. Sikap terhadap pendidikan etika tidak berpengaruh langsung dan tidak langsung secara signifikan terhadap penerapan etika melalui self-efficacy, yang artinya semakin baik persepsi dosen akuntansi terhadap sikap yang dihasilkan dari proses pendidikan etika saat ini tidak berpengaruh dengan dosen akuntansi yang memiliki frekuensi keterlibatan lebih besar dengan memotivasi mahasiswa untuk berpikir etis dalam perkuliahan sehingga dosen akuntansi semakin sering melibatkan kasus etika yang diterapkan dalam perkuliahan.

2. Dukungan ketua program studi berpengaruh tidak langsung secara signifikan terhadap penerapan etika melalui self-efficacy, yang artinya semakin disediakan dukungan finansial dan non finansial oleh ketua program studi dalam membina pendidikan etika maka dosen akuntansi 
memiliki frekuensi keterlibatan lebih besar dengan memotivasi mahasiswa untuk berpikir etis dalam perkuliahan sehingga dosen akuntansi semakin sering melibatkan kasus etika yang diterapkan dalam perkuliahan.

3. Dukungan rekan kerja berpengaruh tidak langsung secara signifikan terhadap penerapan etika melalui self-efficacy, yang artinya rekan kerja yang semakin sering berbagi pengetahuan terkait dengan penerapan etika pendidikan akuntansi maka dosen akuntansi memiliki frekuensi keterlibatan lebih besar dengan memotivasi mahasiswa untuk berpikir etis dalam perkuliahan sehingga dosen akuntansi semakin sering melibatkan kasus etika yang diterapkan dalam perkuliahan.

\section{Saran}

Universitas di harapkan untuk memberikan dukungan kepada ketua program studi dan para dosen yang dibutuhkan untuk meningkatkan self-efficacy dosen, maka dari itu ketua program studi sebaiknya memberikan dukungan secara finansial dan non finansial kepada dosen dalam membina pendidikan etika, dan setiap dosen dapat berbagi pengetahuan dan sumber daya yang terkait dengan pengembangan etika pada pendidikan akuntansi, hal itu dapat meningkatkan frekuensi keterlibatan dosen dalam memotivasi mahasiswa untuk berpikir etis dalam perkuliahan, maka dosen pun dapat menerapkan kasus etika dalam perkuliahan. Untuk penelitian selanjutnya diharapkan dapat mengembangkan sampel nya di perguruan tinggi di Jawa Tengah.

\section{Daftar Pustaka}

Bampton, R. and Cowton, C. J. (2002) The teaching of ethics in management accounting: Progress and prospects. Business Ethics: A European Review, 11(1),52-61.

Bandura, A. 1977. Self-efficacy: Toward a unifying theory of behavioral change. Psychological Review 84(2): 191-215.

Bandura, A. 1982. Self-efficacy mechanism in human agency. American Psychologist 37(2): 122-147.

Bandura, A. 1986. Socials foundations of thought and action: A socialcognitive theory. Englewood Cliffs. NJ: Prentice-Hall.

Bandura, A. 2006. Adolescent development from an agentic perspective. In Self-efficacy Beliefs of Adolescents, edited by Pajares, F., and T. Urdan, 1-43. Greenwich, CT: Information Age.

Bandura, A. 2012. On the functional properties of perceived self-efficay revisted. Journal of Management, 8(1), pp. 9-44.

Blanthorne, C., S. Kovar, and D. Fisher. 2007. Accounting educators' opinions about ethics in the curriculum: An extensive view. Issues in Accounting Education 22 (3): 355-390.

Cavico, F., dan Mujtaba, B. (2009) The State of Business Schools, Business Education and Business Ethics. Journal of Academic and Business Ethics, 2(1), 1-7. 
Cohen, J. R., and L. W. Pant. 1989. Accounting educators' perceptions of ethics in the curriculum. Issues in Accounting Education 4 (1): 70-81.

Dellaportas, M. M., N. Subramaniam, B. J. C. Steven. 2017. Accounting Academics' Teaching Self-Efficacy and Ethics Integration in Accounting Courses: A Malaysian Study. Asian Review of Accounting 25 (1).

Dellaportas, S. 2006. Making a Difference with Deliberate Ethics Interventions. Journal of Business Ethics, 65(4), pp. 391-404.

Evans, F. J., and L. E. Marcal. 2005. Educating forethics: Business deans' perspectives. Business and Society Review 110 (3): 233-248.

Ghaffari, F., O. Kyriacou, and R. Brennan. 2008. Exploring the implementation of ethics in U.K. accounting programs. Issues in Accounting Education 23 (2): 183-198.

Gunz, S., and J. McCutcheon. 1998. Are academics committed to accounting ethics education? Journal of Business Ethics 17 (11): 1145-1154.

Hamidah, S. dan C. K. Marini. 2014. Pengaruh Self-Efficacy, Lingkungan Keluarga, Dan Lingkungan Sekolah Terhadap Minat Berwirausaha Siswa SMK Jasa Boga. https://journal.uny.ac.id/index.php/jpv/article/view/2545

Hartono, J. 2013. Metodologi Penelitian Bisnis: Salah Kaprah dan Pengalaman-pengalaman. Yogyakarta: BPFE Yogyakarta.

IFAC 2016.International Education Standard 4. Initial Professional Development Professional Values, Ethics and Attitudes, International Accounting Education Standards Board.

Madison, R. L. and J. J. Schmidt. 2006. Survey of Time devoted to ethis in accountancy programs in North American colleges and universities. Issues of Accounting Education 21 (2): 99-109.

Massey, D., and J. Van Hise. 2009. Walking the walk: Integrating lessons from multiple perspectives in the development of an accounting ethics course. Issues in Accounting Education, 24 (4): 481-510.

McCormick, J., P. L. Ayres, and B. Beechey. 2006. Teaching self-efficacy, stress and coping in a major curriculum reform: Applying theory to context. Journal of Educational Administration 44 (1): 463-476.

Mintz, S. M. 1990. Ethics in the management accounting curriculum. Management Accounting 71 (12): 51-54.

Moore, W., and M. Esselman. 1992. Teacher efficacy, power, school climate and achievement: A desegregating district's experience.Paper presented at the Annual Meeting of the American Educational Research Association, San Francisco.

Murniati, M. P. S.V. Purnamasari, S. D. Ayu, A. A. advensia, R. Sihombing, dan Y. Warastuti. 
2013. Alat-Alat Pengujian Hipotesis. Semarang: Penerbitan Unika Soegijapranata Semarang.

Narvaez, D., J. L. Vaydich, J. C. Turner, and V. Khmelkov. 2008. Teacher self-efficacy for moral education: Measuring teacher self-efficacy for moral education. Journal of Research in Character Education6 (2): 3-15.

Robbins, S. P, dan T. A. Judge. 2008. Perilaku Organisasi, Edisi 12. Jakarta : Salemba Empat.

Ross, J. A. 1992. Teacher efficacy and the effects of coaching on student achievement. Canadian Journal of Education 17 (1): 51-65.

Skaalvik, E. M., and S. Skaalvik. 2007. Dimensions of teacher self-efficacy and relations with strain factors, perceived collective teacher efficacy, andteacher burnout. Journal of Educational Psychology 99 (3): 611-625. Smylie.

Tschannen, M. and A. W. Hoy. 2001. Teacher efficacy: Capturing an elusive construct. Teaching and Teacher Education 17 (7): 783-805.

Win, Y.Y., S. Ismail, S., and A. Hamid. 2014, Malaysian Accounting Educators' Perceptions on ethics education in the accounting curriculum. Malaysian Accounting Review, 13 (1):1-24.

Wolters, C. A., and S. G. Daugherty. 2007. Goal structures and teachers' sense of efficacy: Their relation and association to teaching experience andacademic level. Journal of Educational Psychology 99 (1): 181-193.

Wood, R., and A. Bandura. 1989. Social cognitive theory of organizational management. The Academy of Management. Review 14 (3): 361-384.

Woolfolk, A. E., and Hoy, W. K. 1990. Prospective teachers' sense of efficacy and beliefs about control. Journal of Educational Psychology, 82 (1): 81-91.

Woolfolk, A. E., B. Rosoff, and W. K. Hoy. 1990. Teachers' sense of efficacy and their beliefs about managing students. Teaching and Teacher Education 6 (2): 137-148. 